\title{
Comparison of the single-step and double-step sous-vide treatment effect on the quality attributes of chicken breast A novel approach to sous-vide
}

ENDRIT HASANI $^{1,2 *}$ @, GYÖRGY KENESEI ${ }^{1}$ and ISTVÁN DALMADI ${ }^{1}$

${ }^{1}$ Department of Livestock Products and Food Preservation Technology, Institute of Food Science and Technology, Hungarian University of Agriculture and Life Sciences, Hungary

${ }^{2}$ Department of Food Technology and Biotechnology, Faculty of Agriculture and Veterinary, University of Prishtina, Kosovo

\section{CONFERENCE FULL PAPER}

Received: June 8, 2021 - Accepted: August 2, 2021

Published online: August 19, 2021

(C) 2021 The Author(s)

\begin{abstract}
Sous-vide treatment is a modern minimal processing cooking technique that uses a single-step temperature of $55-70{ }^{\circ} \mathrm{C}$ and longer time. The quality attributes of meat might be improved by including cooking steps at below $50{ }^{\circ} \mathrm{C}$ temperatures in the sous-vide treatment. The aim of this study was to investigate the effects of the double-step sous-vide treatments on the quality attributes of the chicken breast and comparing with the traditional single-step sous-vide treatments. The single-step sous-vide treatments were performed at $60{ }^{\circ} \mathrm{C}$. In the double-step sous-vide treatments the first step temperature was $45{ }^{\circ} \mathrm{C}$ and the end temperature was $60{ }^{\circ} \mathrm{C}$. Double-step sous-vide treated chicken breasts obtained higher tenderness, moisture content and lower weight loss compared to the single-step sous-vide treated chicken breasts. Double-step sous-vide treatment provided an attractive cooking method to produce high quality chicken breast, however, challenge tests for specific pathogens would be useful for the assessment of the microbiological quality for different treatment combinations.
\end{abstract}

*Corresponding author. E-mail: endrithasani96@gmail.com 


\section{KEYWORDS}

sous-vide, single-step, double-step, shear force, chicken breast

\section{INTRODUCTION}

The consumption of chicken meat shows an important growth along with the simultaneous increasing of pork consumption over the past two decades. Poultry meat represents a healthy diet for many consumers as it is protein rich, fat poor with high content of PUFA (polyunsaturated fatty acids). These properties are beneficial for the human health particularly for the reduction of the cardiovascular diseases, type 2 diabetes and obesity (Marangoni et al., 2015). Considering these advantages, food scientists have been continuously trying to develop new poultry based ready-to-eat (RTE) meals that meet the consumer preferences and expectations. In this sense, sous-vide method has gained tremendous popularity in the recent years in the catering, RTE producers and households mainly resulting from the consumer demand for minimally processed and convenient food with improved natural quality characteristics and high nutritional value (Zavadlav et al., 2020). Sous-vide processing is considered as a uniform heat treatment of food in heat-stable vacuumed pouches kept in circulation water baths at precisely controlled conditions of time and temperature. The traditional sous-vide method uses a single well controlled temperature in the range of $55-70{ }^{\circ} \mathrm{C}$. The treatment time depends on the type, shape and size of the meat (Baldwin, 2012).

Selection of time and temperature parameters used during sous-vide cooking plays an important role on the meat texture changes due to the denaturation of proteins (Zielbauer et al., 2016). It has been reported that consumers prefer chicken legs over chicken breast, as cooked chicken breast has a tougher texture (Hong et al., 2015). Proteolytic enzymes in meat break down the structure of muscle fiber, which results in higher tenderness (Lawrie and Ledward, 2014). From literature, proteolytic enzymes in meat can remain active up to $50{ }^{\circ} \mathrm{C}$ but with higher temperature they start to degrade and inactivate at above $65^{\circ} \mathrm{C}$. The tenderness can be potentially increased by employing the meat's own proteolytic enzymes by fine tuning the sous-vide cooking process by including processing steps below $50{ }^{\circ} \mathrm{C}$. However, careful attention must be taken on this enzyme activation temperature range because it is overlapping the intensive bacterial growth temperature range, which is a possible food safety risk especially in the poultry meat (Yang et al., 2020). According to FSIS (2005), safe poultry product can be produced for the immune-compromised people by a $35 \mathrm{~min}$ heat treatment at $60{ }^{\circ} \mathrm{C}$. Based on our knowledge, no studies in the literature can be found on investigating the effect of the double-step sous-vide cooking on quality attributes of chicken breast. Therefore, in our study we compared the effect of the traditional single-step and the double-step sous-vide treatment on the quality attributes of the sous-vide treated chicken breast.

\section{MATERIALS AND METHODS}

\section{The experimental design of the study}

The raw material used for the study was fresh chicken breasts (musculus pectoralis major) boneless and free of fat and connective tissues. It was purchased at a local market (Budapest, 
Hungary) and was transported without delay to the Department of Animal Products and Preservation Technology, Hungarian University of Agriculture and Life Sciences, Hungary, using an ice filled thermos cool box. Chicken breast meat was cut into uniform pieces (129 $\pm 4 \mathrm{~g}$ weight, $2.0 \pm 0.2 \mathrm{~cm}$ thickness, $7.0 \pm 0.15 \mathrm{~cm}$ width and $9.5 \pm 0.2 \mathrm{~cm}$ length). Chicken breast pieces were randomly selected to form 8 groups consisting of single-step sous-vide treatments (T1, T5) and double-step sous-vide treatment (T2-T4, T6-T8). The first step sous-vide temperature was $45^{\circ} \mathrm{C}$ and the second step temperature was $60{ }^{\circ} \mathrm{C}$ (Table 1). Each treatment was repeated three times.

The raw material was vacuum packed in the PA/PE pouches and subjected to thermal treatment. Prior to vacuum packaging, a data logger equipped with a needle type thermocouple was placed at the thickest point of one of the chicken breasts samples to monitor the internal temperature during cooking. Sous-vide cooking process was carried out in the thermostatic water bath. After finishing the heat treatment the pouches were cooled back in ice water $\left(1^{\circ} \mathrm{C}\right)$. Samples were kept refrigerated $\left(2{ }^{\circ} \mathrm{C}\right)$ prior to the analysis in the next day. The measured parameters were weight loss, $\mathrm{pH}$, moisture content, Lab color attributes and texture properties.

\section{Moisture content, cooking yield and weight loss}

The AOAC International 950.46 method was used to determine the moisture content by calculating the difference between the weights before and after drying of the samples at $105^{\circ} \mathrm{C}$ for $16 \mathrm{~h}$ (AOAC, 2005). Cooking yield and weight loss (\%) were similarly calculated by using weight data of meat samples before and after cooking.

\section{$\mathrm{pH}$}

The $\mathrm{pH}$ was measured with Testo 206 (Hungary) type digital $\mathrm{pH}$ analyzer.

\section{Color}

The meat samples color was measured using chroma meter CR-410 type digital colorimeter (Konica Minolta, Inc. Osaka, Japan). The results are reported as L*(lightness), a* (red-green), and $b^{*}$ (yellow-blue) determined by the CIE Lab color space. The colorimeter was calibrated on a white standard (CRA43) plate supplied by the manufacturer before each measurement. The

Table 1. Processing steps applied in the study

\begin{tabular}{lcc}
\hline Treatments & $\begin{array}{c}\text { Time at the first step temperature of } \\
4{ }^{\circ} \mathrm{C}(\mathrm{min})\end{array}$ & $\begin{array}{c}\text { Time at the end step temperature of } \\
6{ }^{\circ} \mathrm{C}(\mathrm{min})\end{array}$ \\
\hline T1 & 0 & 120 \\
T2 & 40 & 80 \\
T3 & 60 & 60 \\
T4 & 80 & 40 \\
T5 & 0 & 180 \\
T6 & 60 & 120 \\
T7 & 90 & 90 \\
T8 & 120 & 60 \\
\hline
\end{tabular}


measurement was performed on the (cut) inner surface of meat samples in each case. Five to six repetitions were performed for each meat sample.

\section{Texture}

Texture analysis was performed using an SMS TA.XTplus type device (Stable Micro Systems, United Kingdom). The shear force (SF) was measured using an individual slab shape (15 mm width, $15 \mathrm{~mm}$ thickness and $50 \mathrm{~mm}$ length) cooked chicken breast. The samples were cut parallel to the muscle fibers using a Warner-Bratzler flat probe. The speed of the head was $2 \mathrm{~mm} / \mathrm{s}$ before and during measurement. The measured maximum force to shear through the sample, expressed in Newton $(\mathrm{N})$, was used to evaluate the instrumental tenderness of meat. Five cuts were done for each chicken breast sample.

\section{Statistical analysis}

One-Way-ANOVA with post-hoc Tukey test performed with SPSS-23 software (SPSS Inc., IBM Company, USA) was used to detect significant differences between the groups. The differences were considered to be significant at $P \leq 0.05$.

\section{RESULTS AND DISCUSSION}

\section{Moisture content, cooking yield and weight loss}

Moisture content is one of the most important physicochemical attributes in meat along with weight loss. Raw chicken breast showed a moisture content of $74.3 \%$ presented in Table 2 . As expected, all the double-step sous-vide treated chicken breasts obtained higher moisture content compared to the single-step sous-vide treated chicken breast (T1 and T5) (Fig. 1). The doublestep sous-vide treated chicken breast T4 cooked for $80 \mathrm{~min}$ at $45^{\circ} \mathrm{C}$ and $40 \mathrm{~min}$ at $60{ }^{\circ} \mathrm{C}$ showed significantly higher moisture content (\%) compared to the single-step sous-vide treated chicken breast $\mathrm{T} 1$ cooked for $120 \mathrm{~min}$ at $60{ }^{\circ} \mathrm{C}(P \leq 0.05)$. As the cooking time was increased from $40 \mathrm{~min}$ to $80 \mathrm{~min}$ of the first step temperature of $45^{\circ} \mathrm{C}$ it caused an increasing moisture content in the double-step sous-vide treatments (T2-T4). Similar results were obtained in the $3 \mathrm{~h}$ doublestep sous-vide treatments. This can be explained by the fact that lower cooking temperatures result in higher water content in meat because of less release of the muscle fibers sarcoplasmic fluid (Tornberg, 2005).

Table 2. Characterization of chicken breast as raw material

\begin{tabular}{lc}
\hline Parameters & Results \\
\hline Moisture content (\%) & $74.3 \pm 1.24$ \\
Weight (g) & $129 \pm 4$ \\
$\mathrm{~L}^{*}$ & $50.63 \pm 0.93$ \\
$\mathrm{a}^{*}$ & $0.6 \pm 0.16$ \\
$\mathrm{~b}^{*}$ & $3.96 \pm 0.1$ \\
$\mathrm{pH}$ & $5.83 \pm 0.04$ \\
\hline
\end{tabular}

Data are expressed as means $\pm \mathrm{SD}(n=3)$. 


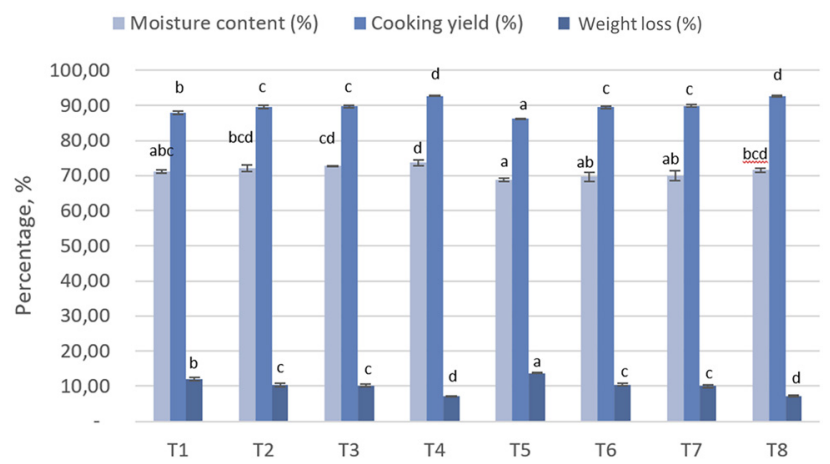

Fig. 1. Moisture content, cooking yield and weight loss of the sous-vide chicken breasts cooked at different time-temperature combinations

Weight loss is directly related to the juiciness of the meat, which can have an impact on the perception of the consumer for the final product (Kerr et al., 2005). The $2 \mathrm{~h}$ and $3 \mathrm{~h}$ double-step sous-vide treatments which included the early first step temperature of $45{ }^{\circ} \mathrm{C}$, gave lower weight loss compared to the $2 \mathrm{~h}$ respectively $3 \mathrm{~h}$ single-step sous-vide treatments at $60{ }^{\circ} \mathrm{C}$ ( $\mathrm{T} 1$ and $\mathrm{T} 5$ ) (Fig. 1). Similar results were observed in the study of Ismail et al. (2019), where the double-step sous-vide cooking treatment reduced the weight loss and improved the water binding capacity of both goat and beef meat. It can be indicated that the lower cooking loss in the case of the doublestep sous-vide treatments are due to the effect of the initial cooking temperature $\left(45^{\circ} \mathrm{C}\right)$. At this temperature myofibrillar transverse shrinking can occur leading to larger space between muscle fibers, thus inter-myofibrillar water can be squeezed out easily (Offer et al., 1984). The cooking loss which is released in the vacuum pack at the initial cooking temperature, seems to be reabsorbed by the meat structure before reaching the final temperature of $60{ }^{\circ} \mathrm{C}$. This is an indicator of the protein denaturation process leading to a specific gel formation and improved fibrillar water binding in the meat (Zielbauer et al., 2016). In general, cooking yield was affected strongly by extending the cooking time of the first step low temperature of $45^{\circ} \mathrm{C}$ in the analyzed sous-vide treatments. Increasing cooking times at the first step temperature increased the cooking yield from 87.96 to $92.8 \%$ in the $2 \mathrm{~h}$ sous-vide treatments (T1-T4) and from 86.24 to $92.68 \%$ at $3 \mathrm{~h}$ sous-vide treatments (T5-T8). All the double-step sous-vide treatments gave significantly higher cooking yield compared to the single-step sous-vide treatments $(P \leq 0.05)$.

T1: $60{ }^{\circ} \mathrm{C}$ for $120 \mathrm{~min}$; T2: $45^{\circ} \mathrm{C}$ for $40 \mathrm{~min}$ and $60{ }^{\circ} \mathrm{C}$ for $80 \mathrm{~min}$; T3: $45^{\circ} \mathrm{C}$ for $60 \mathrm{~min}$ and $60{ }^{\circ} \mathrm{C}$ for $60 \mathrm{~min}$; T4: $45^{\circ} \mathrm{C}$ for $80 \mathrm{~min}$ and $60{ }^{\circ} \mathrm{C}$ for $40 \mathrm{~min}$; T5: $60{ }^{\circ} \mathrm{C}$ for $180 \mathrm{~min}$; T6: $45^{\circ} \mathrm{C}$ for $60 \mathrm{~min}$ and $60{ }^{\circ} \mathrm{C}$ for $120 \mathrm{~min}$; T7: $45^{\circ} \mathrm{C}$ for $90 \mathrm{~min}$ and $60{ }^{\circ} \mathrm{C}$ for $90 \mathrm{~min}$; T8: $45^{\circ} \mathrm{C}$ for $120 \mathrm{~min}$ and $60{ }^{\circ} \mathrm{C}$ for $60 \mathrm{~min}$. Data with different letters mean the significant difference $(P \leq 0.05)$.

\section{$\mathrm{pH}$}

Quality attributes of sous-vide treated chicken breast are shown in Table 3. Chicken breast processed with single- and double-step sous-vide treatments had higher $\mathrm{pH}$ in relation to the raw material $(\mathrm{pH}=5.83)$. The $3 \mathrm{~h}$ single-step sous-vide treatment (T5) had significantly higher $\mathrm{pH}$ compared to the $2 \mathrm{~h}$ single-step sous-vide treatment $(\mathrm{T} 1)(P \leq 0.05)$. Similar results were 
Table 3. Characterization of chicken breast as sous-vide treated samples

\begin{tabular}{|c|c|c|c|c|c|c|c|c|}
\hline \multirow{2}{*}{$\frac{\text { Time }}{\text { Treatments }}$} & \multicolumn{4}{|c|}{$2 \mathrm{~h}$} & \multicolumn{4}{|c|}{$3 \mathrm{~h}$} \\
\hline & $\mathrm{T} 1$ & $\mathrm{~T} 2$ & T3 & $\mathrm{T} 4$ & T5 & T6 & T7 & T8 \\
\hline Shear force $(\mathrm{N})$ & $25.85^{\mathrm{a}}$ & $19.89^{\mathrm{bc}}$ & $19.02^{\text {cde }}$ & $19.05^{\mathrm{cd}}$ & $24.37^{\mathrm{ab}}$ & $16.52^{\text {cde }}$ & $14.03^{\mathrm{de}}$ & $13.61^{\mathrm{e}}$ \\
\hline $\mathrm{L}^{*}$ & $79.99^{\mathrm{a}}$ & $78.55^{\mathrm{bc}}$ & $79.04^{\mathrm{b}}$ & $76.78^{\mathrm{d}}$ & $80.38^{\mathrm{a}}$ & $80.06^{\mathrm{a}}$ & $78.83^{\mathrm{bc}}$ & $78.07^{\mathrm{c}}$ \\
\hline$a^{*}$ & $1.62^{\mathrm{ab}}$ & $2.34^{\mathrm{cd}}$ & $2.32^{\mathrm{cd}}$ & $2.72^{\mathrm{d}}$ & $1.34^{\mathrm{a}}$ & $2.01^{b c}$ & $2.53^{\mathrm{d}}$ & $2.0^{\mathrm{bc}}$ \\
\hline$b^{*}$ & $9.55^{\mathrm{ab}}$ & $9.76^{\mathrm{bc}}$ & $11.62^{\mathrm{e}}$ & $9.96^{\mathrm{cd}}$ & $9.19^{\mathrm{a}}$ & $9.23^{\mathrm{a}}$ & $10.1^{\mathrm{cd}}$ & $10.27^{\mathrm{d}}$ \\
\hline $\mathrm{pH}$ & $6.00^{\mathrm{a}}$ & $6.03^{\mathrm{ab}}$ & $6.03^{\mathrm{ab}}$ & $6.00^{\mathrm{a}}$ & $6.13^{c}$ & $6.08^{b c}$ & $6.04^{\mathrm{ab}}$ & $6.01^{\mathrm{ab}}$ \\
\hline
\end{tabular}

T1: $60{ }^{\circ} \mathrm{C}$ for $120 \mathrm{~min}$; T2: $45{ }^{\circ} \mathrm{C}$ for $40 \mathrm{~min}$ and $60{ }^{\circ} \mathrm{C}$ for $80 \mathrm{~min}$; T3: $45{ }^{\circ} \mathrm{C}$ for $60 \mathrm{~min}$ and $60{ }^{\circ} \mathrm{C}$ for $60 \mathrm{~min}$; T4: $45^{\circ} \mathrm{C}$ for $80 \mathrm{~min}$ and $60{ }^{\circ} \mathrm{C}$ for $40 \mathrm{~min}$; T5: $60{ }^{\circ} \mathrm{C}$ for $180 \mathrm{~min}$; T6: $45^{\circ} \mathrm{C}$ for $60 \mathrm{~min}$ and $60{ }^{\circ} \mathrm{C}$ for $120 \mathrm{~min}$; T7: $45^{\circ} \mathrm{C}$ for $90 \mathrm{~min}$ and $60{ }^{\circ} \mathrm{C}$ for $90 \mathrm{~min}$; T8: $45^{\circ} \mathrm{C}$ for $120 \mathrm{~min}$ and $60{ }^{\circ} \mathrm{C}$ for $60 \mathrm{~min}$. Data with different letters mean the significant difference $(P \leq 0.05)$.

found in other studies where the increasing of cooking time resulted in an increase of the $\mathrm{pH}$ of sous-vide chicken (Naveena et al., 2017). Between the double-step sous-vide treatments there were no significant differences observed regarding $\mathrm{pH}$ values.

\section{Texture}

Tenderness is one of the most important texture parameters for consumers that can be evaluated objectively based on Warner-Bratzler shear force values. Double-step sous-vide treatments tended to decrease the shear force values $(\mathrm{N})$ for chicken breast with the lower values recorded by doublestep treatment T8 (Table 3). The low shear force values for the double-step sous-vide treatments could be explained by desmin degradation in myofibrillar muscle component that is known to be an indicator of the extent of meat tenderization during proteolysis (Zhang et al., 2006). Davey and Gilbert (1976) have found an exponential relation between the proteolytic activity and temperatures up to $40{ }^{\circ} \mathrm{C}$. This may be the reason why the double-step sous-vide method using the temperature of $45{ }^{\circ} \mathrm{C}$ showed lower shear force values in the case of chicken breast.

\section{Color}

Color parameters are usually used as indicative features of the quality and attractiveness of the product for consumers. The changes in color parameters in sous-vide treated meat can be caused by myoglobin denaturation, the oxidative state of myoglobin, $\mathrm{pH}$ and less by Maillard reactions because of the use of low temperatures in the sous-vide method (Ayub and Ahmad, 2019). With the exception of T6 treatment, lightness $\left(\mathrm{L}^{*}\right)$ was significantly lower in all of the $2 \mathrm{~h}$ and $3 \mathrm{~h}$ double-step sous-vide treatments compared to the $2 \mathrm{~h}$ and $3 \mathrm{~h}$ single-step sous-vide treatment (T1 and T5) $(P \leq 0.05)$ (Table 3$)$. Similar results were introduced by Ismail et al. (2019) in sousvide treated cattle and goat cooked at single-step and two-step treatments. In our study chicken breast showed a pale appearance $\left(\mathrm{L}^{*}>53\right)$ in both single-step and double-step sous-vide treatments based on the $\mathrm{L}^{*}$ values (Da-Silva Buzanello et al., 2019).

The $\mathrm{a}^{*}$ value was measured in the range of 1.53-2.72. Redness was significantly higher in all of the $2 \mathrm{~h}$ and $3 \mathrm{~h}$ double-step sous-vide treatments compared to the $2 \mathrm{~h}$ and $3 \mathrm{~h}$ single-step sousvide treatment (T1 and T5) $(P \leq 0.05)$. These results show that the redness was preserved in the $2 \mathrm{~h}$ and $3 \mathrm{~h}$ double-step sous-vide treated chicken breast. Treatments preserved better the 
myoglobin molecules because the denaturation of myoglobin starts well over the applied treatment temperatures $\left(55\right.$ and $65{ }^{\circ} \mathrm{C}$ ) (Hunt et al., 1999). The $b^{*}$ value ranged from 9.19 to 11.62. Double-step sous-vide treated chicken breasts showed higher yellowness than those cooked using a single-step sous-vide method (Table 3). This can be explained with the fact that the cooking period of the double-step sous-vide cooked chicken breasts exposed to the second temperature $\left(60^{\circ} \mathrm{C}\right)$ was shorter than that of single-step sous-vide cooked chicken breasts.

\section{CONCLUSIONS}

The present study reveals that cooking conditions significantly affected the physiochemical quality attributes of sous-vide chicken breast. Double-step sous-vide treatments provided an attractive cooking method to produce high quality chicken breast as it reduced shear force values while obtained higher moisture content, redness and lower weight loss of chicken breast as compared to the traditional single-step sous-vide treatment. According to FSIS (2005) it takes $35 \mathrm{~min}$ at $60{ }^{\circ} \mathrm{C}$ of cooking poultry to be made safe even for the immune-compromised people. The selected time and temperature combination treatments seems to meet the food safety criteria; however, it would be useful to carry out challenge tests of specific pathogens to assess the effectiveness of the treatment combination on microbiological quality.

\section{ACKNOWLEDGMENT}

The Authors wish to thank the European Union and the European Social Fund for supporting our research work (grant agreement no. EFOP-3.6.3-VEKOP-16-2017-00005).

\section{REFERENCES}

AOAC. (2005). AOAC Official Methods of Analysis, 18th ed. AOAC International, Rockville, MD, USA; ISBN 0935584870.

Ayub, H. and Ahmad, A. (2019). Physiochemical changes in sous vide and conventionally cooked meat. International Journal of Gastronomy and Food Science, 17: 100145.

Baldwin, D.E. (2012). Sous vide cooking: A review. International Journal of Gastronomy and Food Science, 1(1): 15-30.

Da Silva-Buzanello, R.A., Schuch, A.F., Gasparin, A.W., Torquato, A.S., Scremin, F.R., Canan, C., and Soares, A.L. (2019). Quality parameters of chicken breast meat affected by carcass scalding conditions. Asian-Australasian Journal of Animal Sciences, 32(8): 1186.

Davey, C.L. and Gilbert, K.V. (1976). The temperature coefficient of beef ageing. Journal of the Science of Food and Agriculture, 27(3): 244-250.

FSIS (2005). Time-temperature tables for cooking ready-to-eat poultry products. Notice 16-05. Food Safety and Inspection Service.

Ismail, I., Hwang, Y.H., and Joo, S.T. (2019). Comparison of single and double combination of temperature-time in sous vide treated semitendinosus muscle from cattle and goat. Food Science of Animal Resources, 39(1): 45. 
Hong, G.E., Kim, J.H., Ahn, S.J., and Lee, C.H. (2015). Changes in meat quality characteristics of the sousvide cooked chicken breast during refrigerated storage. Korean Journal for Food Science of Animal Resources, 35(6): 757.

Hunt, M.C., Sørheim, O., and Slinde, E. (1999). Color and heat denaturation of myoglobin forms in ground beef. Journal of Food Science, 64(5): 847-851.

Kerr, W.L., Wang, X., and Choi, S.G. (2005). Physical and sensory characteristics of low-fat Italian sausage prepared with hydrated oat. Journal of Food Quality, 28(1): 62-77.

Lawrie, R.A. and Ledward, D. (2014). Lawrie's Meat Science. Woodhead Publishing.

Marangoni, F., Corsello, G., Cricelli, C., Ferrara, N., Ghiselli, A., Lucchin, L., and Poli, A. (2015). Role of poultry meat in a balanced diet aimed at maintaining health and wellbeing: an Italian consensus document. Food \& Nutrition Research, 59(1): 27606.

Naveena, B.M., Khansole, P.S., Shashi Kumar, M., Krishnaiah, N., Kulkarni, V.V., and Deepak, S.J. (2017). Effect of sous vide processing on physicochemical, ultrastructural, microbial and sensory changes in vacuum packaged chicken sausages. Food Science and Technology International, 23(1): 75-85.

Offer, G., Restall, D., and Trinick, J. (1984). Water-holding in meat. Recent Advances in Chemistry of Meat, 71-86.

Tornberg, E.V.A. (2005). Effects of heat on meat proteins-Implications on structure and quality of meat products. Meat Science, 70(3): 493-508.

Yang, X., Wang, H., Badoni, M., Zawadski, S., McLeod, B., Holman, D., and Uttaro, B. (2020). Effects of a novel three-step sous vide cooking and subsequent chilled storage on the microbiota of beef steaks. Meat Science, 159: 107938.

Zavadlav, S., Blažić, M., Van de Velde, F., Vignatti, C., Fenoglio, C., Piagentini, A.M., Pirovani, M.E., Perotti, C.M., Bursać Kovačević, D., and Putnik, P. (2020). Sous vide as a technique for preparing healthy and high-quality vegetable and seafood products. Foods, 9(11): 1537.

Zielbauer, B.I., Franz, J., Viezens, B., and Vilgis, T.A. (2016). Physical aspects of meat cooking: time dependent thermal protein denaturation and water loss. Food Biophysics, 11(1): 34-42.

Zhang, W.G., Lonergan, S.M., Gardner, M.A., and Huff-Lonergan, E. (2006). Contribution of postmortem changes of integrin, desmin and $\mu$-calpain to variation in water holding capacity of pork. Meat Science, 74(3): 578-585.

Open Access. This is an open-access article distributed under the terms of the Creative Commons Attribution 4.0 International License (https://creativecommons.org/licenses/by/4.0/), which permits unrestricted use, distribution, and reproduction in any medium, provided the original author and source are credited, a link to the CC License is provided, and changes - if any - are indicated. (SID_1) 